\title{
Assessment of some heavy metals in various aquatic plants of Al-Hawizeh Marsh, southern of Iraq
}

\author{
DUNYA A.H. AL-ABBAWY ${ }^{1, \vartheta}$, BASIM M. HUBAIN AL-THAHAIBAWI ${ }^{2}$, ITHAR K.A. AL-MAYALY ${ }^{3}$, \\ KADHIM H. YOUNIS \\ ${ }^{1}$ Department of Ecology, College of Science, University of Basrah. Basrah, Iraq. \\ 'email: dunya.hussain@uobasrah.edu.iq \\ ${ }^{2}$ Ministry of Environment/Directorate Environment of Maysan. Maysan, Iraq \\ ${ }^{3}$ Department of Biology, College of Science, University of Baghdad. Baghdad, Iraq \\ ${ }^{4}$ Department of Marine Vertebrates, Marine Science Centre, University of Basrah. Basrah, Iraq
}

Manuscript received: 25 October 2020. Revision accepted: 25 December 2020

\begin{abstract}
Al-Abbawy DAH, Al-Thahaibawi BMH, Al-Mayaly IKA, Younis KH. 2021. Assessment of some heavy metals in various aquatic plants of Al-Hawizeh Marsh, southern of Iraq. Biodiversitas 22: 338-345. In order to describe the degree of contamination of aquatic environments in Iraq, heavy metals analysis ( $\mathrm{Fe}, \mathrm{Ni}, \mathrm{Cr}, \mathrm{Cd}, \mathrm{Pb}$, and $\mathrm{Zn}$ ) was conducted for six aquatic macrophytes from different locations of Al-Hawizeh Marsh in southern Iraq. The six species were Azolla filiculoides (floating plant), Ceratophyllum demersum, Potamogeton pectinatus, Najas marina (submerged plants), Phragmites australis, and Typha domingensis (emergent plants). The results indicate that cadmium, chromium, and iron concentrations in aquatic plants were above the World Health Organization (WHO). In contrast, zinc, copper, and lead were within the allowable limits. C. demersum and N. marina showed higher concentrations of heavy metal accumulation than the other aquatic plants. The concentration of heavy metals in plant tissues during the summer months was higher than in the different seasons. $C$. demersum and $N$. marina showed higher concentrations of heavy metal accumulation than the other aquatic plants. Heavy metal bioconcentration (BCF) was calculated to assess heavy metals bioaccumulation in the aquatic plants.
\end{abstract}

Keywords: Accumulation, Al-Hawizeh Marsh, biodiversity, heavy metals, Iraq, macrophytes

\section{INTRODUCTION}

Iraq is a country that faces a real challenge in water sufficiency and quality. Restoration and reflooding of drained marshes in Iraq after 2003 need expounded research. Al-Hawizeh Marsh is considered to be evaluated for risk assessment of heavy metals. Aquatic ecosystems are affected by several health stressors that significantly deplete biodiversity. In the future, the loss of biodiversity and its effects are predicted to be more significant for aquatic ecosystems than for terrestrial ecosystems (AlHomaidan et al. 2020; Geist and Hawkins 2016). One such stressor is the increased pollution and inadequate consideration for environmental impacts of aquatic environments from agricultural practices, industrial development, and urbanization. The indiscriminate release of organic and inorganic liquid wastes and airborne deposition change the physio-chemical characteristics of water, causing hazards to aquatic flora and fauna, and humans (Ghorade et al. 2015). Heavy metals are especially toxic in the environment due to their ability to bind with proteins and prevent DNA replication (Tchounwou et al. 2012). Further, plants accumulate heavy metals at concentrations many times higher than that of the surrounding waters (Bai et al. 2018).

Heavy metals are the naturally occurring elements in the earth's crust, but uncontrolled anthropic inputs have severely altered these metals' natural biogeochemical cycles. After being released from the earth's crust, heavy metals persist in the environment for a long time because they are non-degradable (Wu et al. 2010). Because heavy metals exert toxic effects on microorganisms, plants, animals, and humans, their contamination in the environment has become one of the biggest environmental issues of the present time and is of even greater concern for the future. Several heavy metals, including iron $(\mathrm{Fe})$, cobalt $(\mathrm{Co})$, copper $(\mathrm{Cu})$, manganese $(\mathrm{Mn})$, and zinc $(\mathrm{Zn})$, are crucial for the metabolic activity of biota at low concentrations and are considered essential elements or micronutrients (Peralta-Videa et al. 2009). But when heavy metals concentration exceeds a certain threshold, they produce adverse effects (Ali et al. 2013; Geist and Hawkins 2016).

Heavy metals enter the aquatic environment from both anthropogenic and natural sources (Ghorab 2018)where they are partitioned throughout various aquatic environmental compartments (water, suspended solids, sediments, and biota) and can lead to deleterious effects which may be acutely or chronically toxic to aquatic life within the affected area. Many studies have shown that aquatic plants are sinks for heavy metals in aquatic ecosystems (Xing et al. 2013). Generally, factors such as the stage of plant growth, plant species, and characteristics of the metals themselves affect absorption rates and accumulation in aquatic flora (Rucińska-Sobkowiak 2016). 
For example, studies have shown that floating plants such as water hyacinth (Eichhornia crassipes) (Newete et al. 2016), emergent plants such as cattail (Typha latifolia) (Duman et al. 2015), and submerged plants such as Ceratophyllum demersum (Romero-Oliva et al. 2015) and Potamogeton malaianus (Harguinteguy et al. 2014) have significant capacity to accumulate heavy metals.

Generally, the accumulation capabilities of aquatic plants are the most pronounced in submerged plants and decrease in capacity in floating plants and emergent plants, but this is often influenced directly by the plant species and other parameters in the aquatic environment (Harguinteguy et al. 2014). The metal concentrations in water typically reflect the current conditions, whereas sediments are reservoirs of heavy metals that may have been deposited in the aquatic environment long ago. Aquatic plants can uptake large amounts of metals from water and sediments via both active and passive absorption by different organs such as roots, stems, and leaves, making these plants suitable for heavy metal amelioration in the aquatic environment (Cai et al. 2018). Moreover, measuring the accumulation of heavy metals in various aquatic plants can provide time-integrated information about metals in aquatic ecosystems.

Bioconcentration factor (BCF) is usually used to assess heavy metal bioaccumulation (Usman et al. 2019). BCF can be defined as the ratio of the steady-state metal ions concentration in the plant versus the concentration in water. The development and expansion of chemical compounds used in Iraq industries lead to the widespread deposition of heavy metals into the environment. Increasing pollution of heavy metals of Iraq southern marshes has been the subject of considerable interest (Al-Saad and Mustafa, 1994). Although plants are considered an essential part of these marshes' food web (Al-Saadi and Al-Mousawi 1988), little is known about the region's plant ecology. Only slightly more is known about the limnological parameters.

In this work, concentrations of $\mathrm{Fe}, \mathrm{Cu}, \mathrm{Zn}, \mathrm{Ni}, \mathrm{Cr}, \mathrm{Cd}$, and $\mathrm{Pb}$ in aquatic plant species (Ceratophyllum demersum L., Potamogeton pectinatus L, Najas marina L, Phragmites australis (Cav.) Trin. ex Steud., Typha domingensis Pers., and Azolla filiculoides Lam.) from the Al-Hawizeh Marsh were determined. We compared the composition of aquatic plant species and heavy metal bioaccumulation in the study area; previous literature included Al-Abbawy and AlMayah (2010) and Al-Haidarey et al. (2010).

The purpose of this paper was to study macrophyte species composition of Huwaizah marsh, determination of the heavy metal concentrations in chosen macrophyte species, and to evaluate heavy metals bioconcentration factors (BCFs).

\section{MATERIALS AND METHODS}

\section{Study area}

Al-Hawizeh Marsh lies to the east of the Tigris River, straddling the Iran-Iraq border, and is approximately $70 \mathrm{~km}$ from Ammara. The marsh is distributed with $79 \%$ in Iraq and $21 \%$ in Iran (Muhsin 2011), extending between (latitude/longitude: $31^{\circ} 00^{\prime}-31^{\circ} 45^{\prime} \mathrm{N}, 47^{\circ} 25^{\prime}-47^{\circ} 50^{\prime} \mathrm{E}$ ). It is about $80 \mathrm{~km}$ in length, from the Iraqi-Iranian borders to the east of the Tigris River, and about $30-40 \mathrm{~km}$ wide (Khudair 2018). Thus, the marsh size is approximately $2400 \mathrm{~km}^{2}$, which expands to $3500 \mathrm{~km}^{2}$ during the flood season and shrinks to $650 \mathrm{~km}^{2}$ during dry seasons with only the deepwater areas remaining. This marsh's reservoir retains about 7000 billion $\mathrm{m}^{3}$ of water and is 2-4 meters above sea level (Orson et al. 1992). The marsh is mostly fed by the Tigris River's main tributaries near Al-Ammarah city, known as the Al-Musharah and Al-Kahla Rivers (Figure 1). It is also provided by rainfall and rivers flowing from Iran, such as the Al-Karkha, Tayib, and Duwayaraj, which empty into the Sanaf Marsh, supplying the AlHawizeh Marsh. The climate in the marsh is arid subtropical, with less than 200 millimeters of annual rainfall. It is considered by hot summers (with average of around $43^{\circ} \mathrm{C}$ ) and cool winters (with average of around $4^{\circ} \mathrm{C}$ ). In the summer, dust storms are common, and heatwaves can raise the temperature to $48^{\circ} \mathrm{C}$. Humidity is low, and evaporation from free water surfaces is high, causing water losses due to evaporation (Hashim et al. 2019).

\section{Sampling and heavy metal determination \\ Water sample analysis}

Water samples were taken from different sites distributed around the marsh collected every season $(n=20)$. The sampling procedure involves water samples from the subsurface $(10 \mathrm{~cm})$. A representative sample of water (1000 mL) was added in HDPE bottles, previously washed with $\mathrm{HNO}_{3}$ solution. To determination the heavy metals concentrations, all collected samples were prepared. In this respect, water samples' digestion with aqua regia $\left(\mathrm{HNO}_{3}\right.$ 67\%: $\mathrm{HCl} 37 \%=3: 1$ ) was achieved.

\section{Plant sampling}

Six specimens (whole plant samples) of each mature species of the three plant groups (1 x free-floating, $2 \mathrm{x}$ emergents, and $3 \mathrm{x}$ sub-emergents) were collected seasonally from each location during December 2017 and November 2018. Plant samples were collected manually $(n=20)$, washed with water and sonicate from the marsh, and saved in plastic bags until they reached the laboratory. Samples were then thoroughly cleaned using running tap water and rinsed with deionized water (Orson et al. 1992). The plant samples were then oven-dried at $100^{\circ} \mathrm{C}$ for 24 hours and pulverized with an electric blender to a fine powder for easy digestion and then sieved through a $2 \mathrm{~mm}$ mesh sieve. Next, $5 \mathrm{~mL}$ of $4: 1$ mixture of $\mathrm{HNO}_{3}: \mathrm{HCIO}_{4}$ was added to $1 \mathrm{~g}$ of plant weighed with an analytical weighing balance. This was then heated at a temperature of $105^{\circ} \mathrm{C}$ for 1 hour until dried (Kakulu and Jacob 2006)and allowed to cool. It was added to a volumetric flask filled to the $50 \mathrm{~mL}$ mark with $1 \mathrm{M} \mathrm{HNO}_{3}$. The solution was centrifuged using a HARRIER 15/80 model centrifuge for $30 \mathrm{~min}$ then transferred into sampling bottles for analysis. Heavy metal determination (LIST) of both water and plant samples digested were analyzed using Jena 300 Analyst AAS (Atomic Absorption Spectrophotometer) from Germany. 

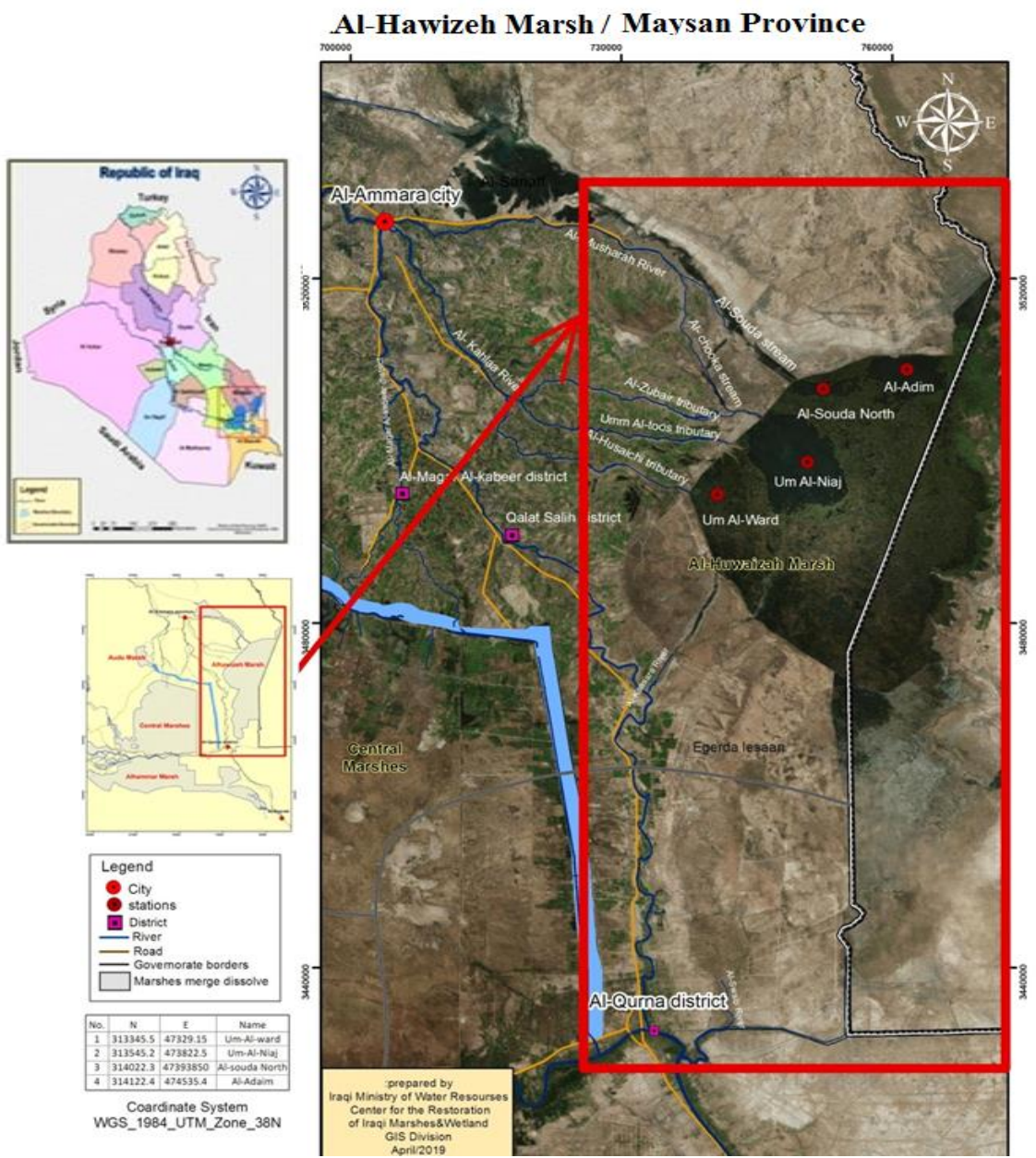

Figure 1. Al-Hawizeh Marsh location in Maysan Province, southern Iraq. (Source: CRIM 2019)

Bioconcentration factor (BCF) values were calculated as described by Gobas et al. (2009) where:

$$
\mathrm{BCF}=\mathrm{C}_{\text {macrophyte }}\left(\mathrm{mg} . \mathrm{Kg}^{-1}\right) / \mathrm{C}_{\text {water }}\left(\mathrm{mg} \mathrm{l}^{-1}\right)
$$

\section{Statistical analysis}

Differences in heavy metal concentration among the species and the seasons were tested using a Two-way ANOVA with post-hoc comparisons made using Fisher's least significant difference (LSD). The test for normality and variance homogeneity was carried first.

\section{RESULTS AND DISCUSSION}

\section{Heavy metals in water}

Concentrations of heavy metals (Fe, $\mathrm{Cu}, \mathrm{Ni}, \mathrm{Zn}, \mathrm{Cr}, \mathrm{Pb}$, and $\mathrm{Cd}$ ) in Al-Hawizeh Marsh were below the permissible limits in water according to (MPDC, 1967). Metals concentration in water ranked as the following trend: $\mathrm{Fe}>\mathrm{Ni}>\mathrm{Cr}>\mathrm{Cd}>\mathrm{Pb}>\mathrm{Zn}$. Furthermore, the Iron $(\mathrm{Fe})$, Nickel $(\mathrm{Ni})$, and Zinc $(\mathrm{Zn})$ showed a higher concentration of metals in water than other metals (Table 1).
The highest mean \pm standard deviation (SD) of Iron was $0.091 \pm 0.0373 \mathrm{mg} / \mathrm{L}^{-1}$ during the spring, while the lowest was $0.028 \pm 0.0096 \mathrm{mg} / \mathrm{L}^{-1}$ during winter. The results showed significant differences $(\mathrm{P} \leq 0.05)$ were detected in Iron $(\mathrm{Fe})$ values among seasons, where the highest values recorded during spring and the lowest values detected during the winter.

\section{Bioaccumulation of heavy metals in Macrophytes species}

Six aquatic plant species belonging to six families were found and collected from four stations within Al-Hawizeh Marsh during the winter, spring, summer, and autumn seasons. The species belonged to six families: Ceratophyllaceae, Potamogetonaceae, Najadaceae, Salviniaceae, Poaceae, and Typhaceae. The samples were either submerged, free-floating, or emergent species, all within the flowering plant (Angiospermae), as shown in Table 2.

The study results showed that the heavy metals concentrations varied among plant samples during the AlHawizeh Marsh study. Concentrations and mean \pm SD of heavy metals found in the plants during the four seasons are shown in Table 3 and Figures 2 to 8. 
Table 1. Concentrations and (mean \pm standard deviation (SD)) of heavy metals (ppm) and permissible values in water samples of AlHawizeh Marsh, Iraq during the four seasons

\begin{tabular}{lllllll}
\hline Metal & Winter & Spring & Summer & Autumn & Average & $\mathbf{\pm S D}$ \\
\hline Iron $(\mathrm{Fe})$ & 0.02850 & 0.09075 & 0.03900 & 0.04250 & 0.05019 & 0.027688 \\
Nickel $(\mathrm{Ni})$ & 0.0028 & 0.0105 & 0.0213 & 0.0077 & 0.01056 & 0.007817 \\
Chrome $(\mathrm{Cr})$ & 0.0002 & 0.0013 & 0.0026 & 0.0005 & 0.00116 & 0.001067 \\
Cadmum $(\mathrm{Cd})$ & 0.0002 & 0.0014 & 0.0009 & 0.0016 & 0.00103 & 0.000602 \\
Lead $(\mathrm{Pb})$ & 0.0013 & 0.0018 & 0.0110 & 0.0043 & 0.00456 & 0.004488 \\
Zinc $(\mathrm{Zn})$ & 0.0083 & 0.0445 & 0.0540 & 0.0248 & 0.03288 & 0.020444 \\
\hline
\end{tabular}

Table 2. List of families and macrophytes species according to habitat, general appearance, habit, and plant group in Al-Hawizeh Marsh, Iraq

\begin{tabular}{llllll}
\hline Family & Macrophyte species & Habitat & $\begin{array}{l}\text { General } \\
\text { appearance }\end{array}$ & Habit & Plant group \\
\hline Ceratophyllaceae & Ceratophyllum demersum L. & Submerged & Herb & Perennial & Dicot \\
Potamogetonaceae & Potamogeton pectinatus L. & Submerged & Herb & Perennial & Monocot \\
Najadaceae & Najas marina L. & Submerged & Herb & Perennial & Monocot \\
Salviniaceae & Azolla filiculoides Lam. & Free-floating & Fern & Perennial & Fern \\
Poaceae & Phragmites australis (Cav)Trin. ex Steud & Emergent & Grass & Perennial & Monocot \\
Typhaceae & Typha domingensis Pers. & Emergent & Herb & Perennial & Monocot \\
\hline
\end{tabular}

Table 3. Concentrations and (mean \pm standard deviation (SD)) of heavy metals $(\mathrm{mg} / \mathrm{kg} \mathrm{Dw})$ and permissible values in aquatic plants of Al-Hawizeh Marsh, Iraq during the four seasons

\begin{tabular}{cllll}
\hline $\begin{array}{c}\text { Aquatic } \\
\text { plant }\end{array}$ & \multicolumn{1}{c}{ Winter } & \multicolumn{1}{c}{ Spring } & Summer & Autumn \\
\hline Azolla filiculoides & & & \\
$\mathrm{Fe}$ & $55.6625 \mathrm{~d}^{*}$ & $71.1575 \mathrm{c}$ & $91.6425 \mathrm{a}$ & $82.525 \mathrm{~b}$ \\
& \pm 0.668 & \pm 0.271 & \pm 0.514 & \pm 0.318 \\
$\mathrm{Ni}$ & $1.445 \mathrm{a}$ & $1.045 \mathrm{~b}$ & $0.9575 \mathrm{c}$ & $0.625 \mathrm{~d}$ \\
& \pm 0.012 & \pm 0.012 & \pm 0.035 & \pm 0.012 \\
$\mathrm{Cr}$ & $0.14 \mathrm{c}$ & $0.08 \mathrm{~d}$ & $1.25525 \mathrm{a}$ & $0.7475 \mathrm{~b}$ \\
& \pm 0.008 & \pm 0.014 & \pm 0.045 & \pm 0.029 \\
$\mathrm{Cd}$ & $0.1625 \mathrm{~d}$ & $0.2675 \mathrm{c}$ & $0.61 \mathrm{a}$ & $0.4225 \mathrm{~b}$ \\
& \pm 0.018 & \pm 0.017 & \pm 0.026 & \pm 0.027 \\
$\mathrm{~Pb}$ & $0.44 \mathrm{~d}$ & $0.6225 \mathrm{c}$ & $0.8625 \mathrm{a}$ & $0.665 \mathrm{~b}$ \\
& \pm 0.018 & \pm 0.018 & \pm 0.017 & \pm 0.020 \\
$\mathrm{Zn}$ & $0.15 \mathrm{~d}$ & $9.355 \mathrm{ab}$ & $9.36 \mathrm{a}$ & $8.5025 \mathrm{c}$ \\
& \pm 0.008 & \pm 0.023 & \pm 0.034 & \pm 0.078 \\
$\mathrm{Ceratophyllum}$ demersum & & & \\
$\mathrm{Fe}$ & $724.3925 \mathrm{~b}$ & $325.32 \mathrm{~d}$ & $795.82 \mathrm{a}$ & $676.71 \mathrm{c}$ \\
& \pm 1.755 & \pm 1.171 & \pm 4.289 & \pm 1.211 \\
$\mathrm{Ni}$ & $2.5825 \mathrm{a}$ & $1.73 \mathrm{~b}$ & $0.611 \mathrm{~cd}$ & $0.855 \mathrm{c}$ \\
& \pm 0.483 & \pm 0.064 & \pm 0.014 & \pm 0.059 \\
$\mathrm{Cr}$ & $1.915 \mathrm{~b}$ & $0.3325 \mathrm{~d}$ & $2.7075 \mathrm{a}$ & $1.545 \mathrm{c}$ \\
& \pm 0.020 & \pm 0.022 & \pm 0.392 & \pm 0.083 \\
$\mathrm{Cd}$ & $0.3125 \mathrm{~d}$ & $0.6275 \mathrm{c}$ & $0.85225 \mathrm{~b}$ & $0.94 \mathrm{a}$ \\
& \pm 0.017 & \pm 0.022 & \pm 0.023 & \pm 0.025 \\
$\mathrm{~Pb}$ & $1.16 \mathrm{~b}$ & $1.0375 \mathrm{c}$ & $1.51025 \mathrm{a}$ & $1.2775 \mathrm{~b}$ \\
& \pm 0.109 & \pm 0.116 & \pm 0.204 & \pm 0.062 \\
$\mathrm{Zn}$ & $0.32 \mathrm{~d}$ & $8.505 \mathrm{c}$ & $13.18625 \mathrm{a}$ & $10.475 \mathrm{~b}$ \\
& \pm 0.021 & \pm 0.064 & \pm 0.140 & \pm 0.270 \\
Najas marina & & & & \\
$\mathrm{Fe}$ & $393.2795 \mathrm{~d}$ & $442.596 \mathrm{c}$ & $551.4525 \mathrm{~b}$ & $577.075 \mathrm{a}$ \\
& \pm 2.555 & \pm 0.797 & \pm 0.984 & \pm 1.335 \\
$\mathrm{Ni}$ & $1.2675 \mathrm{~b}$ & $1.525 \mathrm{a}$ & $0.274 \mathrm{~d}$ & $0.455 \mathrm{c}$ \\
& \pm 0.168 & \pm 0.089 & \pm 0.041 & \pm 0.034 \\
$\mathrm{Cr}$ & 0.265 & 0.24 & 2.67025 & 1.755 \\
& \pm 0.015 & \pm 0.013 & \pm 0.412 & \pm 0.103 \\
$\mathrm{Cd}$ & $0.23 \mathrm{~d}$ & $0.295 \mathrm{c}$ & $0.91075 \mathrm{a}$ & $0.865 \mathrm{~b}$ \\
& \pm 0.018 & \pm 0.012 & \pm 0.008 & \pm 0.031 \\
$\mathrm{~Pb}$ & $0.9 \mathrm{~b}$ & $1.3025 \mathrm{a}$ & $0.56 \mathrm{~d}$ & $0.755 \mathrm{c}$ \\
& \pm 0.092 & \pm 0.102 & \pm 0.014 & \pm 0.045 \\
& & & &
\end{tabular}

\begin{tabular}{lllll} 
& & & \\
$\mathrm{Zn}$ & $0.24 \mathrm{~d}$ & $8.2675 \mathrm{a}$ & $7.33575 \mathrm{~b}$ & $6.45525 \mathrm{c}$ \\
& \pm 0.067 & \pm 0.225 & \pm 0.227 & \pm 0.483 \\
Typha domingensis & & & \\
$\mathrm{Fe}$ & $82.1975 \mathrm{c}$ & $251.445 \mathrm{a}$ & $64.3575 \mathrm{~d}$ & $110.875 \mathrm{~b}$ \\
& \pm 0.884 & \pm 0.491 & \pm 0.458 & \pm 0.309 \\
$\mathrm{Ni}$ & $1.3775 \mathrm{~b}$ & $7.5125 \mathrm{a}$ & $0.33825 \mathrm{~d}$ & $0.5725 \mathrm{c}$ \\
& \pm 0.030 & \pm 0.068 & \pm 0.017 & \pm 0.035 \\
$\mathrm{Cr}$ & $0.36 \mathrm{~d}$ & $0.6625 \mathrm{c}$ & $1.6555 \mathrm{a}$ & $1.455 \mathrm{~b}$ \\
& \pm 0.016 & \pm 0.030 & \pm 0.040 & \pm 0.020 \\
$\mathrm{Cd}$ & $0.2675 \mathrm{~d}$ & $0.86 \mathrm{a}$ & $0.379 \mathrm{c}$ & $0.77 \mathrm{~b}$ \\
& \pm 0.043 & \pm 0.025 & \pm 0.021 & \pm 0.018 \\
$\mathrm{~Pb}$ & 0.65 & 0.945 & 0.57 & 0.865 \\
& \pm 0.040 & \pm 0.034 & \pm 0.031 & \pm 0.026 \\
$\mathrm{Zn}$ & $0.2575 \mathrm{~d}$ & $11.05 \mathrm{a}$ & $6.08825 \mathrm{~b}$ & $5.3725 \mathrm{c}$ \\
& \pm 0.068 & \pm 0.238 & \pm 0.094 & \pm 0.042 \\
$\mathrm{Potamogeton}$ pectinatus & & & \\
$\mathrm{Fe}$ & $389.12 \mathrm{~b}$ & $419.2575 \mathrm{a}$ & $310.6425 \mathrm{c}$ & $289.35 \mathrm{~d}$ \\
& \pm 1.759 & \pm 0.804 & \pm 0.577 & \pm 0.574 \\
$\mathrm{Ni}$ & $1.44 \mathrm{a}$ & $1.19 \mathrm{~b}$ & $0.244 \mathrm{~d}$ & $0.74 \mathrm{c}$ \\
& \pm 0.228 & \pm 0.104 & \pm 0.009 & \pm 0.043 \\
$\mathrm{Cr}$ & $0.2725 \mathrm{c}$ & $0.255 \mathrm{c}$ & $1.13 \mathrm{a}$ & $0.925 \mathrm{~b}$ \\
& \pm 0.033 & \pm 0.042 & \pm 0.146 & \pm 0.026 \\
$\mathrm{Cd}$ & $0.2075 \mathrm{~b}$ & $0.8125 \mathrm{a}$ & $0.85325 \mathrm{a}$ & $0.8375 \mathrm{a}$ \\
& \pm 0.017 & \pm 0.061 & \pm 0.005 & \pm 0.037 \\
$\mathrm{~Pb}$ & $0.325 \mathrm{~d}$ & $0.855 \mathrm{a}$ & $0.4365 \mathrm{c}$ & $0.77 \mathrm{~b}$ \\
& \pm 0.012 & \pm 0.040 & \pm 0.005 & \pm 0.018 \\
$\mathrm{Zn}$ & $0.22 \mathrm{~d}$ & $7.29 \mathrm{a}$ & $6.21625 \mathrm{~b}$ & $4.4 \mathrm{c}$ \\
& \pm 0.025 & \pm 0.256 & \pm 0.213 & \pm 0.182 \\
$\mathrm{Phragmites}$ & australis & & & \\
$\mathrm{Fe}$ & $118.355 \mathrm{c}$ & $379.145 \mathrm{a}$ & $93.37 \mathrm{~d}$ & $142.9325 \mathrm{~b}$ \\
& \pm 0.142 & \pm 0.970 & \pm 0.487 & \pm 0.548 \\
$\mathrm{Ni}$ & $2.3875 \mathrm{c}$ & $7.225 \mathrm{a}$ & $2.19925 \mathrm{~d}$ & $3.235 \mathrm{~b}$ \\
& \pm 0.101 & \pm 0.123 & \pm 0.103 & \pm 0.055 \\
$\mathrm{Cr}$ & $6.5475 \mathrm{a}$ & $0.365 \mathrm{~d}$ & $1.299 \mathrm{~b}$ & $0.8525 \mathrm{c}$ \\
& \pm 0.106 & \pm 0.031 & \pm 0.047 & \pm 0.030 \\
$\mathrm{Cd}$ & $0.305 \mathrm{~d}$ & $0.7375 \mathrm{c}$ & $0.8445 \mathrm{~b}$ & $0.9275 \mathrm{a}$ \\
& \pm 0.059 & \pm 0.022 & \pm 0.004 & \pm 0.017 \\
$\mathrm{~Pb}$ & $0.945 \mathrm{c}$ & $1.9425 \mathrm{a}$ & $0.86925 \mathrm{~d}$ & $1.2175 \mathrm{~b}$ \\
& \pm 0.044 & \pm 0.049 & \pm 0.018 & \pm 0.062 \\
& $0.3225 \mathrm{~d}$ & $8.87 \mathrm{a}$ & $6.27475 \mathrm{~b}$ & $5.62 \mathrm{c}$ \\
$\mathrm{No}$ & \pm 0.027 & \pm 0.065 & \pm 0.060 & \pm 0.097 \\
\hline & & & &
\end{tabular}

Note: Same numbers mean no significant differences among them $(\mathrm{p}<0.05)$ 


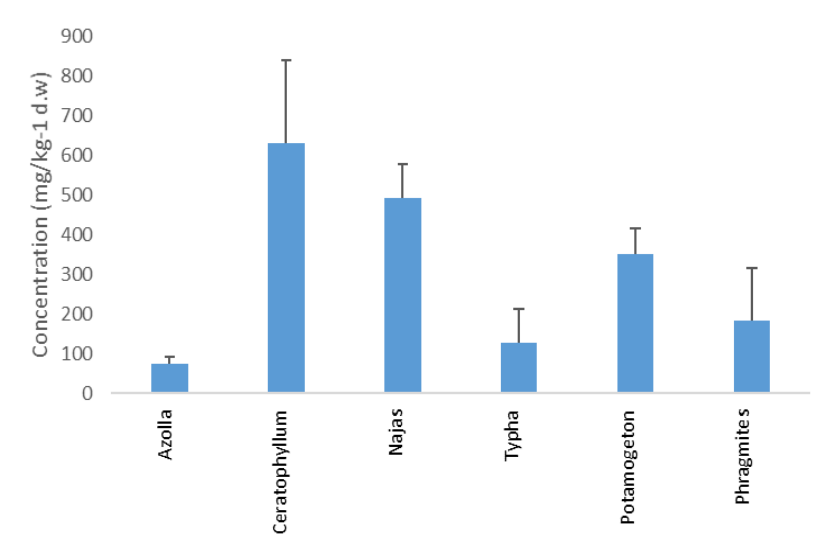

Figure 2. Concentrations of $\mathrm{Fe}\left(\mathrm{mg} / \mathrm{kg}^{-1} \mathrm{dry}\right.$ wt.) in aquatic plant species from Al-Hawizeh Marsh, Iraq

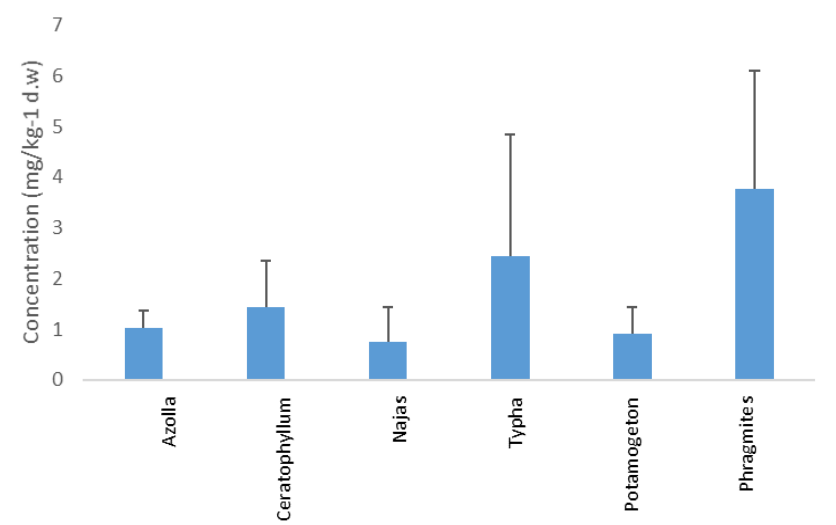

Figure 3. Concentrations of $\mathrm{Ni}\left(\mathrm{mg} / \mathrm{kg}^{-1}\right.$ dry wt.) in aquatic plant species of Al-Hawizeh Marsh, Iraq

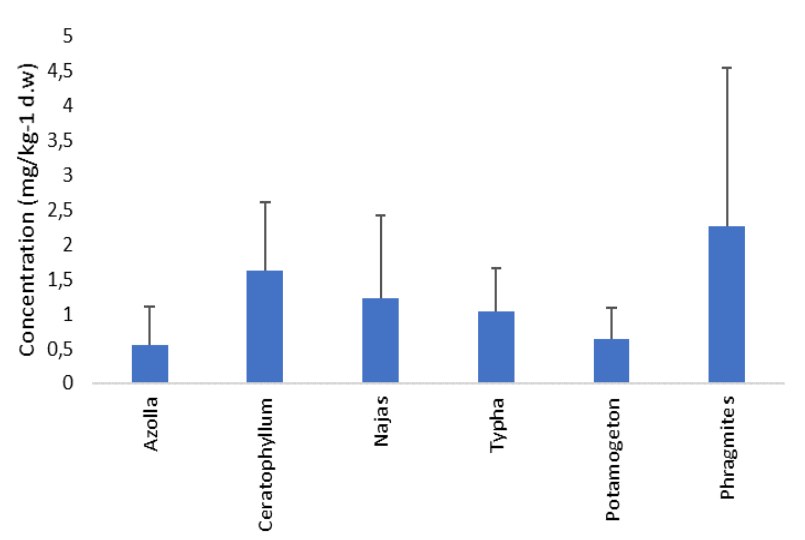

Figure 5. Concentrations of $\mathrm{Cr}\left(\mathrm{mg} / \mathrm{kg}^{-1}\right.$ dry wt.) in aquatic plant species of Al-Hawizeh Marsh, Iraq

The concentrations of iron $(\mathrm{Fe})$ ranged from 55.66 $\mathrm{mg} / \mathrm{kg}^{-1}$ dry wt. in Azolla filiculoides in the winter to $795.82 \mathrm{mg} / \mathrm{kg}^{-1}$ dry wt. in $C$. demersum during the summer (Figure 2). However, the highest mean and standard deviation results for Fe were $630.56 \pm 209.29 \mathrm{mg} / \mathrm{kg}^{-1}$ dry wt. within $C$. demersum, while the lowest (mean $\pm \mathrm{SD}$ ) value

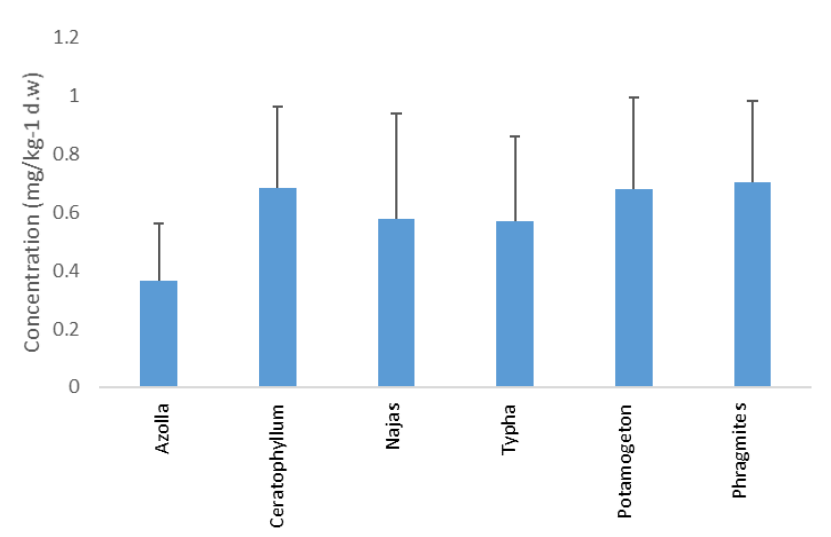

Figure 6. Concentrations of $\mathrm{Cd}\left(\mathrm{mg} / \mathrm{kg}^{-1}\right.$ dry wt.) in aquatic plant species of Al-Hawizeh Marsh, Iraq

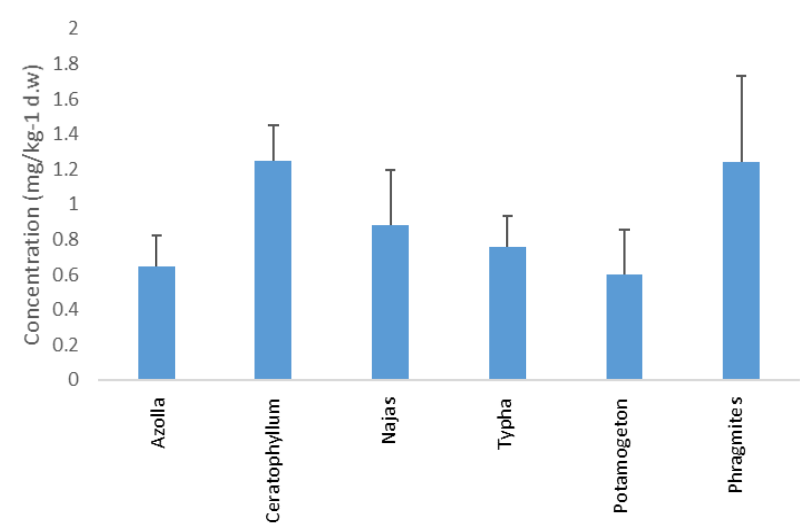

Figure 7. Concentrations of $\mathrm{Pb}(\mathrm{mg} / \mathrm{kg}$ dry wt.) in aquatic plant species of Al-Hawizeh Marsh, Iraq

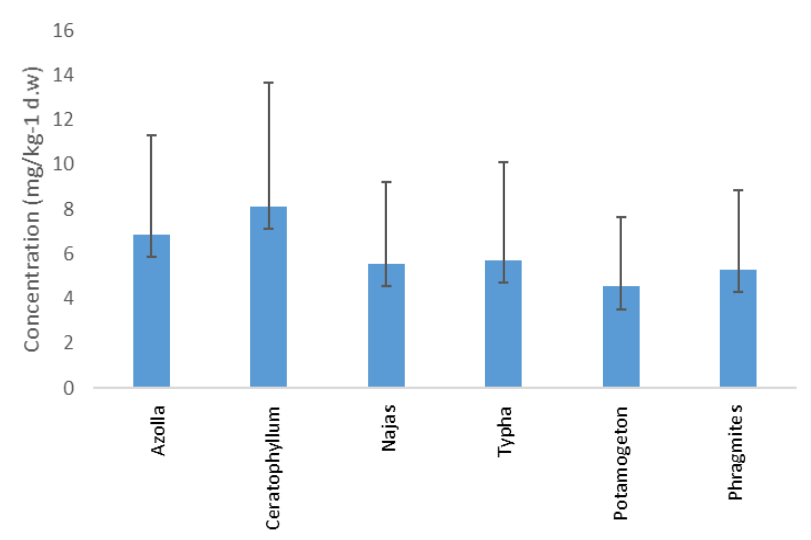

Figure 8. Concentrations of $\mathrm{Zn}(\mathrm{mg} / \mathrm{kg}$ dry wt.) in aquatic plant species of Al-Hawizeh Marsh, Iraq

for $\mathrm{Fe}$ was $75.34 \pm 15.51 \mathrm{mg} / \mathrm{kg}^{-1} \mathrm{dry}$ wt. within $A$. filiculoides (Table 3). The differences detected in $\mathrm{Fe}$ concentrations among aquatic plant species during the study period were significant $(\mathrm{P} \leq 0.05)$. In all plant samples, the iron concentration was above the permissible limit (20 mg/kg) (WHO 2006). The higher amounts of Fe 
in each season may have resulted from broader contamination by leachate migration. Vegetation that absorbs excessive amounts of Fe and other metals (Table 1) may adversely influence the health of animals living within the marsh ecosystem (Vongdala et al. 2018).

Nickel (Ni) ranged from $0.244 \mathrm{mg} / \mathrm{kg}^{-1}$ dry wt. in $P$. pectinatus during the summer to $7.51 \mathrm{mg} / \mathrm{kg}^{-1} \mathrm{dry}$ wt.) in $P$. australis during spring (Figure 3). The highest mean and standard deviation of $\mathrm{Ni}, 10.33 \pm 2.19 \mathrm{mg} / \mathrm{kg}^{-1}$ dry wt.., was found in the $C$. demersum sample. In contrast, the lowest, $3.48 \pm 0.66 \mathrm{mg} / \mathrm{kg}^{-1}$ dry wt., was recorded in A. filiculoides (Table 3). The final concentrations were beyond the permissible limits recommended by WHO (10 mg/kg). The differences in concentrations of Nickel $(\mathrm{Ni})$ among aquatic plant species were not significant $(\mathrm{P}>0.05)$ except for $P$. australis and T. domingensis.

Chromium $(\mathrm{Cr})$ concentrations varied from $0.08 \mathrm{mg} / \mathrm{kg}^{-1}$ dry wt.in A. filiculoides during the spring to $6.54 \mathrm{mg} / \mathrm{kg}^{-1}$ dry wt. in $P$. australis during the winter (Figure 5). The highest Cr value was $2.26 \pm 2.87 \mathrm{mg} / \mathrm{kg}^{-1}$ dry wt. recorded in $P$. australis, while the lowest value was $0.55 \pm 0.54 \mathrm{mg} / \mathrm{kg}^{-1}$ dry wt. in $A$. filiculoides (Table 3). The differences in concentrations of chromium $(\mathrm{Cr})$ among aquatic plant species were significant $(\mathrm{P}<0.05)$. The concentration of $\mathrm{Cr}$ in $C$. demersum and $P$. australis was above the permissible limit during winter, in $C$. demersum, $N$. marina, $P$. australis, and $T$. domingensis during summer, and in $C$. demersum, $N$. marina, and $T$. domingensis during autumn. This was compared with limits recorded by Meharg (2011)

Cadmium (Cd) in plant samples differed from $0.16 \mathrm{mg} / \mathrm{kg}^{-1}$ dry wt. in A. filiculoides during the winter to $0.94 \mathrm{mg} / \mathrm{kg}^{-1}$ dry wt. in $C$. demersum during the autumn (Figure 6). The highest Cd value was $0.70 \pm 0.27 \mathrm{mg} / \mathrm{kg}^{-1}$ dry wt. in $P$. pectinatus, while the lowest value was $0.36 \pm 0.19 \mathrm{mg} / \mathrm{kg}^{-1}$ dry wt.in A. filiculoides (Table 3). The differences in concentrations of Cadmium $(\mathrm{Cd})$ among aquatic plant species were found not significant $(\mathrm{P}<0.05)$. In all plants, cadmium concentration was above the permissible limit $(0.02 \mathrm{mg} / \mathrm{kg})$. Cd is relatively mobile in soils and thus readily available for plants, although the uptake mechanisms are not well known (Thakur et al. 2016).

Lead $(\mathrm{Pb})$ concentrations in plant samples ranged between $0.33 \mathrm{mg} / \mathrm{kg}^{-1}$ dry wt. in $P$. pectinatus during the winter to $1.98 \mathrm{mg} / \mathrm{kg}^{-1}$ dry wt. in $C$. demersum during the summer (Figure 7). The highest $\mathrm{Pb}$ value was $1.25 \pm 0.49$ $\mathrm{mg} / \mathrm{kg}^{-1}$ dry wt. in $P$. australis, while the lowest value was $0.65 \pm 0.17 \mathrm{mg} / \mathrm{kg}$ dry wt. in A. filiculoides (Table 3). Nonsignificant differences $(\mathrm{P}>0.05)$ were found in concentrations of lead $(\mathrm{Pb})$ among the studied aquatic plant species. In all plant samples, the concentration of lead was below the permissible limit. In plants with high lead concentrations, the production of reactive oxygen species (ROS) quickens, causing lipid membrane damage that ultimately leads to damaged chlorophyll and photosynthetic processes and suppresses the overall growth of the plant (Najeeb et al. 2017).

Concentrations of zinc $(\mathrm{Zn})$ in plant samples ranged from $4.6 \mathrm{mg} / \mathrm{kg}^{-1}$ dry wt.in $P$. pectinatus during the autumn to $13.303 \mathrm{mg} / \mathrm{kg}^{-1}$ dry wt. in $C$. demersum during the summer (Figure 8). The highest $\mathrm{Zn}$ value was $10.98 \pm 1.97$ $\mathrm{mg} / \mathrm{kg}^{-1}$ dry wt.in $C$. demersum, while the lowest value was $5.98 \pm 1.13 \mathrm{mg} / \mathrm{kg}^{-1}$ dry wt. They were recorded in $P$. pectinatus (Table 3 ). The differences in concentrations of Zinc (Zn) among aquatic plant species were not found to be significant $(\mathrm{P}>0.05)$.

The study results showed that BCF of the heavy metals varied among plant samples during the Al-Hawizeh Marsh study, as shown in Table 4. The bioconcentration factor describes the uptake rate of metals by plants from their surrounding environment. the bioconcentration factor was calculated as the ratio between the metal concentration in plant tissue and its concentration in water. Concentrations of heavy metals in aquatic plants are known to be a useful tool for environmental research. Soluble fractions of metal cations are rapidly caught either by clays or organic compounds and deposited in bottom sediments, or root tissues of aquatic plants absorb them. Metals usually soluble in the aquatic phase by dissolution.

Table 4. Bioconcentration factor of heavy metals in aquatic plants of Al-Hawizeh Marsh, Iraq during the four seasons

\begin{tabular}{|c|c|c|c|c|c|}
\hline Plant & Metal & Winter & Spring & Summer & Autumn \\
\hline 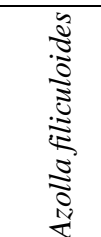 & $\begin{array}{l}\mathrm{Fe} \\
\mathrm{Ni} \\
\mathrm{Cr} \\
\mathrm{Cd} \\
\mathrm{Pb} \\
\mathrm{Zn}\end{array}$ & $\begin{array}{l}1953.070 \\
525.454 \\
700.00 \\
722.2222 \\
352.00 \\
18.18182\end{array}$ & $\begin{array}{l}784.1047 \\
99.52381 \\
61.53846 \\
187.7193 \\
355.7143 \\
210.2247\end{array}$ & $\begin{array}{l}2349.808 \\
45.05882 \\
482.7885 \\
659.4595 \\
78.40909 \\
172.2685\end{array}$ & $\begin{array}{l}1941.765 \\
80.90615 \\
1423.81 \\
272.5806 \\
159.4118 \\
343.5354\end{array}$ \\
\hline 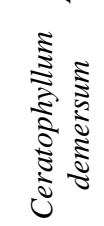 & $\begin{array}{l}\mathrm{Fe} \\
\mathrm{Ni} \\
\mathrm{Cr} \\
\mathrm{Cd} \\
\mathrm{Pb} \\
\mathrm{Zn}\end{array}$ & $\begin{array}{l}25417.28 \\
939.0909 \\
9575.0 \\
1388.889 \\
928.0 \\
38.78788\end{array}$ & $\begin{array}{l}3584.793 \\
164.7619 \\
255.7692 \\
440.3509 \\
592.8571 \\
191.1236\end{array}$ & $\begin{array}{l}20405.64 \\
28.75294 \\
1041.346 \\
921.3514 \\
137.2955 \\
244.1898\end{array}$ & $\begin{array}{l}15922.59 \\
110.6796 \\
4800.0 \\
606.4516 \\
300.5882 \\
423.2323\end{array}$ \\
\hline 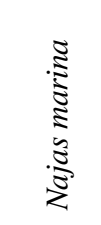 & $\begin{array}{l}\mathrm{Fe} \\
\mathrm{Ni} \\
\mathrm{Cr} \\
\mathrm{Cd} \\
\mathrm{Pb} \\
\mathrm{Zn}\end{array}$ & $\begin{array}{l}13799.28 \\
460.9091 \\
1325.0 \\
1022.222 \\
720.0 \\
29.09091\end{array}$ & $\begin{array}{l}4877.091 \\
145.2381 \\
184.6154 \\
207.0175 \\
744.2857 \\
185.7865\end{array}$ & $\begin{array}{l}14139.81 \\
12.89412 \\
1027.019 \\
984.5946 \\
50.90909 \\
135.8472\end{array}$ & $\begin{array}{l}13578.24 \\
58.89968 \\
3342.857 \\
558.0645 \\
177.6471 \\
260.8182\end{array}$ \\
\hline 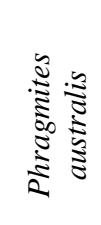 & $\begin{array}{l}\mathrm{Fe} \\
\mathrm{Ni} \\
\mathrm{Cr} \\
\mathrm{Cd} \\
\mathrm{Pb} \\
\mathrm{Zn}\end{array}$ & $\begin{array}{l}4152.807 \\
868.1818 \\
32737.5 \\
1355.556 \\
756 \\
39.09091\end{array}$ & $\begin{array}{l}4177.906 \\
688.0952 \\
280.7692 \\
517.5439 \\
1110 \\
199.3258\end{array}$ & $\begin{array}{l}2394.103 \\
103.4941 \\
499.6154 \\
912.973 \\
79.02273 \\
116.1991\end{array}$ & $\begin{array}{l}3363.118 \\
418.7702 \\
1623.81 \\
598.3871 \\
286.4706 \\
227.0707\end{array}$ \\
\hline 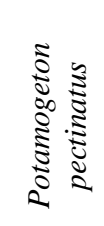 & $\begin{array}{l}\mathrm{Fe} \\
\mathrm{Ni} \\
\mathrm{Cr} \\
\mathrm{Cd} \\
\mathrm{Pb} \\
\mathrm{Zn}\end{array}$ & $\begin{array}{l}13653.33 \\
523.6364 \\
1362.5 \\
922.2222 \\
260 \\
26.66667\end{array}$ & $\begin{array}{l}4619.917 \\
113.3333 \\
196.1538 \\
570.1754 \\
488.5714 \\
163.8202\end{array}$ & $\begin{array}{l}7965.192 \\
11.48235 \\
434.6154 \\
922.4324 \\
39.68182 \\
115.1157\end{array}$ & $\begin{array}{l}6808.235 \\
95.79288 \\
1761.905 \\
540.3226 \\
181.1765 \\
177.7778\end{array}$ \\
\hline 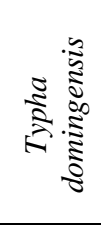 & $\begin{array}{l}\mathrm{Fe} \\
\mathrm{Ni} \\
\mathrm{Cr} \\
\mathrm{Cd} \\
\mathrm{Pb} \\
\mathrm{Zn}\end{array}$ & $\begin{array}{l}2884.123 \\
500.9091 \\
1800 \\
1188.889 \\
520 \\
31.21212\end{array}$ & $\begin{array}{l}2770.744 \\
715.4762 \\
509.6154 \\
603.5088 \\
540 \\
248.3146\end{array}$ & $\begin{array}{l}1650.192 \\
15.91765 \\
636.7308 \\
409.7297 \\
51.81818 \\
112.7454\end{array}$ & $\begin{array}{l}2608.824 \\
74.11003 \\
2771.429 \\
496.7742 \\
203.5294 \\
217.0707\end{array}$ \\
\hline
\end{tabular}


The BCF values for the plants confirmed the hypothesis indicating the species as an accumulator for different metals. The BCF value for metals indicates the plants are suitable species for phytoremediation purposes (Nirola et al. 2015).

Mesopotamian marshes are easily influenced by environmental factors such as surface runoff, groundwater, dissolution from sediment, deposition from the atmosphere, and anthropogenic pollutants (Al-Saad et al. 2010) Therefore, the variation in heavy metal accumulation results could have been attributed to the interactions between the numerous factors that affect the concentrations of dissolved metals, such as the phytoplankton and aquatic plant densities absorbing or adsorbing the ionic metals, and the fuel burn emissions within the marsh during the summer season (Al-Haidarey et al. 2010).

Although $\mathrm{Cr}, \mathrm{Cd}$, and $\mathrm{Zn}$ are known as essential elements to plants, higher concentrations of these heavy metals can be toxic (Karthick et al. 2012). The accumulation of $\mathrm{Pb}, \mathrm{Cd}$, and $\mathrm{Cr}$ in plants of $\mathrm{Al}-\mathrm{Hawizeh}$ Marsh may have been from the discharge of sewage from houses and treatment units in the Maysan province. On the other hand, heavy metals' absorption varies depending on the plant species (Shahid et al. 2016). It is affected by the metals' bioavailability, the extent of their survival in the water, the $\mathrm{pH}$, and the sediments' organic matter content. The accumulation of heavy metals varies between plant species and between the individual plant parts (roots, stems, leaves) (Yabanli et al. 2014).

The concentration of heavy metals in the tissues of plants during the summer was higher than in any of the other seasons, which may have been due to increased salinity and $\mathrm{pH}$, which works to increase deposition of suspended materials in sediments as well as organic carbon in sediments which absorb the heavy metals. In this case, plants have a greater chance of absorbing these metals from the sediments through their roots and storing them in other parts. This is consistent with the research conducted by others (Farhood 2016).

Wetland plants can accumulate heavy metals through their roots and shoots. They are often proposed as pollution monitoring organisms (Eid et al. 2020), although the metal concentrations vary with the plant species and the wetland type. In this study, the lowest concentration of $\mathrm{Zn}$ was 0.15 $\mathrm{mg} / \mathrm{kg}$ in A. filiculoides during the winter, while it was $13.303 \mathrm{mg} / \mathrm{kg}$ dry wt. in $C$. demersum during the summer, suggesting that the plants of Al-Hawizeh Marsh were not contaminated. In our study, $\mathrm{Cu}$ concentrations were $3.25 \mathrm{mg} / \mathrm{kg}$ in A. filiculoides, but were $7.47 \mathrm{mg} / \mathrm{kg}$ in $T$. domingensis during the spring, implying $\mathrm{Cu}$ contamination in plants is not severe. Though heavy metals like $\mathrm{Cd}, \mathrm{Pb}$, and $\mathrm{Ni}$ are not essential for plant growth, they may accumulate in plants (Singh et al. 2011) where they are readily taken up and accumulated in toxic forms. Heavy metal concentrations in the soil solution play a vital role in controlling metal bioavailability to plants.

Several plants, such as $P$. australis, $P$. pectinatus, and $T$. domingensis, play a significant role in phytoremediation, as they are the best and cheapest clean-up technologies for contaminated water, groundwater, and wastewater.
However, the high contamination of heavy metals in these plants affects cattle's health, which requires further investigation. Although some metals are essential for biological systems in humans and animals, acting as structural and catalytic components of proteins and enzymes, in higher concentrations, they can be toxic (Nazir et al. 2015; Liu et al. 2017). This study is the first to examine plants' heavy metal contamination in the AlHawizeh Marsh in the last ten year.

Overall, our results showed that concentrations of cadmium, chromium, and iron in plants were above the permissible limits set by WHO. In contrast, zinc, copper, and lead were all below the allowable limits.

\section{ACKNOWLEDGEMENTS}

The authors acknowledge the Department of Biology, the University of Baghdad, Iraq for supporting this project.

\section{REFERENCES}

Al-Abbawy DAH, Al-Mayah AA. 2010. Ecological survey of aquatic macrophytes in restored marshes of Southern Iraq during 2006 and 2007. Marsh Bull 5 (2):177-196.H.

Al-Haidarey MJS, Hassan FM, Al-Kubaisey ARA, Douabul AaZ. 2010. The geoaccumulation index of some heavy metals in Al-Hawizeh Marsh, Iraq. E-J Chem. DOI: 10.1155/2010/839178

Al-Homaidan AA, Al-Otaibi TG, El-Sheikh MA, Al-Ghanayem AA, Ameen F. 2020. Accumulation of heavy metals in a macrophyte Phragmites australis: Implications to phytoremediation in the Arabian Peninsula wadis. Environ Monit Assess 192 (3): 202. DOI: 10.1007/s10661-020-8177-6

Ali H, Khan E, Sajad M. 2013. Phytoremediation of heavy metalsConcepts and applications. Chemosphere 91. DOI: 10.1016/j.chemosphere.2013.01.075

Al-Saad HT, Mustafa YZ. 1994. Pollutants in the sediment of Iraqi marshes: A review. In: Hussain NA (eds.). Ahwar of Iraq Environmental Approach. Marine Science Centre Puplication 18, Iraq.

Al-Saad HT, Al-Hello MA, Al-Taein SM, DouAbul AAZ. 2010. Water quality of the Iraqi southern marshes. Mesopotamian J Marine Science 25 (2): 188-204.

Al-Saadi HA, Al-Mousawi AH. 1988. Some notes on the ecology of aquatic plants in the Al-Hammar marsh, Iraq. Vegetatio 75 (3): 131133.

Bai L, Liu X.-L, Hu J, Li J, Wang Z.-L, Han G, Li S.-L, Liu C.-Q. 2018. Heavy Metal Accumulation in Common Aquatic Plants in Rivers and Lakes in the Taihu Basin. Intl J Environ Res and Public Health 15 (12). DOI: 10.3390/ijerph15122857

Hashim BM, Sultan MA, Attyia MN, Maliki AA, Al-Ansari N. 2019. Change Detection and Impact of Climate Changes to Iraqi Southern Marshes Using Landsat 2 MSS, Landsat 8 OLI and Sentinel 2 MSI Data and GIS Applications. Applied Sci 9 (10): 2016. doi:10.3390/app9102016

Cai S, Shen Z, Ni Z, Li Y, Liu B, Dai Y, Zhao J. 2018. Metal distribution in water, sediment, submerged plant, and fish from an urban river in Zunyi, southwest of China. FRESENIUS ENVIRON BULLETIN 27 (3): 1627-1633

Duman F, Urey E, Koca FD. 2015. Temporal variation of heavy metal accumulation and translocation characteristics of narrow-leaved cattail (Typha angustifolia L.). Environ Sci and Pollution Res 22 (22): 17886-17896. DOI: 10.1007/s11356-015-4979-4

Eid EM, Galal TM, Sewelam NA, Talha NI, Abdallah SM. 2020. Phytoremediation of heavy metals by four aquatic macrophytes and their potential use as contamination indicators: A comparative assessment. Environ Sci and Pollution Res 27 (11): 12138-12151. DOI: $10.1007 / \mathrm{s} 11356-020-07839-9$ 
Farhood AT. 2016. Water quality status in different aquatic environments in Thi-Qar province based on NSF-WQI. J Thi-Qar Sci 6 (1): 17-24.

Geist J, Hawkins SJ. 2016. Habitat recovery and restoration in aquatic ecosystems: Current progress and future challenges. Aquat Conserv Mar Freshw Ecosyst 26 (5): 942-962. DOI: 10.1002/aqc. 2702

Ghorab MA. 2018. Environmental pollution by heavy metals in the aquatic ecosystems of Egypt. Open Access J Toxicol 3 (1). DOI: 10.19080/OAJT.2018.03.555603

Ghorade IB, Jadhavar VR, Patil SS. 2015. Assessment of heavy metal content in Amba river water (Maharashtra). World J Pharma Pharmaceut Sci 4 (5): 1853-1860.

Harguinteguy CA, Cirelli AF, Pignata ML. 2014. Heavy metal accumulation in leaves of aquatic plant Stuckenia filiformis and its relationship with sediment and water in the Suquía river (Argentina). Microchem J 114: 111-118.

Kakulu SE, Jacob JO. 2006. Comparison of digestion methods for trace metal determination in moss samples. Proceeding of the 1st National Conference of the Faculty of Science, University of Abuja, Nigeria.

Karthick P, Siva Sankar R, Kaviarasan T, Mohanraju R. 2012. Ecological implications of trace metals in seaweeds: Bio-indication potential for metal contamination in Wandoor, South Andaman Island. Egyptian J Aquat Res 38 (4): 227-231. DOI: 10.1016/j.ejar.2013.01.006

Khudair DBH. 2018. Water Quality Assessment and Total Dissolved Solids Prediction using Artificial Neural Network in Al-Hawizeh Marsh South of Iraq. J Eng 24 (4): 10.

Liu J, Cao L, Dou S. 2017. Bioaccumulation of heavy metals and health risk assessment in three benthic bivalves along the coast of Laizhou Bay, China. Mar Pollut Bull 117 (1-2): 98-110.

Meharg AA. 2011. Trace Elements in Soils and Plants. 4th ed. CRC Press, Boca Raton, FL, USA.

Muhsin IJ. 2011. Al-Hawizeh Marsh monitoring method using remotely sensed images. Iraqi J Sci 7:-

Najeeb U, Ahmad W, Zia MH, Zaffar M, Zhou W. 2017. Enhancing the lead phytostabilization in wetland plant Juncus effusus L. through somaclonal manipulation and EDTA enrichment. Arabian J Chem 10: S3310-S3317.

Nazir R, Khan M, Masab M, Rehman HU, Rauf NU, Shahab S, Ameer N, Sajed M, Ullah M, Rafeeq M. 2015. Accumulation of heavy metals $(\mathrm{Ni}, \mathrm{Cu}, \mathrm{Cd}, \mathrm{Cr}, \mathrm{Pb}, \mathrm{Zn}, \mathrm{Fe})$ in the soil, water and plants and analysis of physico-chemical parameters of soil and water collected from Tanda Dam Kohat. J Pharmaceut Sci Res 7 (3): 89.

Newete SW, Erasmus BF, Weiersbye IM, Byrne MJ. 2016. Sequestration of precious and pollutant metals in biomass of cultured water hyacinth (Eichhornia crassipes). Environ Sci Pollut Res 23 (20): 20805-20818.

Nirola R, Megharaj M, Palanisami T, Aryal R, Venkateswarlu K, Ravi Naidu. 2015. Evaluation of metal uptake factors of native trees colonizing an abandoned copper mine-a quest for phytostabilization. J Sustain Mining 14 (3): 115-123. DOI: 10.1016/j.jsm.2015.11.001

Orson RA, Simpson RL, Good RE. 1992. A mechanism for the accumulation and retention of heavy metals in tidal freshwater marshes of the upper Delaware River estuary. Estuar Coastal Shelf Sci 34 (2): 171-186.

Peralta-Videa JR, Lopez ML, Narayan M, Saupe G, Gardea-Torresdey J. 2009. The biochemistry of environmental heavy metal uptake by plants: Implications for the food chain. Intl J Biochem Cell Biol 41 (8-9): 1665-1677.

Rai UN, Sinha S. 2001. Distribution of metals in aquatic edible plants: Trapa natans (Roxb.) Makino and Ipomoea aquatica Forsk. Environ Monit Assess 70 (3): 241-252.

Romero-Oliva CS, Contardo-Jara V, Pflugmacher S. 2015. Time dependent uptake, bioaccumulation and biotransformation of cell free crude extract microcystins from Lake Amatitlán, Guatemala by Ceratophyllum demersum, Egeria densa and Hydrilla verticillata. Toxicon 105: 62-73.

Rucińska-Sobkowiak R. 2016. Water relations in plants subjected to heavy metal stresses. Acta Physiologiae Plantarum 38 (11): 257. DOI: 10.1007/s11738-016-2277-5

Salman JM. 2006. Environmental study of potential pollution in the Euphrates River between Hindiya dam and Kufa region-Iraq [Dissertation]. Faculty of Science, University of Babylon, Iraq.

Shahid M, Dumat C, Khalid S, Schreck E, Xiong T, Niazi NK. 2016. Foliar heavy metal uptake, toxicity and detoxification in plants: A comparison of foliar and root metal uptake. J Hazard Mater 325: 3658. DOI: $10.1016 /$ j.jhazmat.2016.11.063

Singh R, Gautam N, Mishra A, Gupta R. 2011. Heavy metals and living systems: An overview. Indian J Pharmacol 43 (3): 246-253. DOI: 10.4103/0253-7613.81505

Tchounwou PB, Yedjou CG, Patlolla AK, Sutton DJ. 2012. Heavy metals toxicity and the environment. EXS 101: 133-164. DOI: 10.1007/9783-7643-8340-4 6

Thakur S, Singh L, Wahid ZA, Siddiqui MF, Atnaw SM, Din MF. M. 2016. Plant-driven removal of heavy metals from soil: Uptake, translocation, tolerance mechanism, challenges, and future perspectives. Environ Monit Assess 188 (4): 206. DOI: 10.1007/s10661-016-5211-9.

Usman K, Al-Ghouti MA, Abu-Dieyeh MH. 2019. The assessment of cadmium, chromium, copper, and nickel tolerance and bioaccumulation by shrub plant Tetraena qataranse. Sci Rep 9. DOI: 10.1038/s41598-019-42029-9.

Vongdala N, Tran H.-D, Xuan TD, Teschke R, Khanh TD. 2018. Heavy metal accumulation in water, soil, and plants of municipal solid waste landfill in Vientiane, Laos. Intl J Environ Res Public Health 16 (1): 22. PubMed. DOI: 10.3390/ijerph16010022.

Wu M, Lu T.-J, Ling F.-Y, Sun J, Du H.-Y. 2010. Research on the architecture of Internet of Things. 2010 3rd International Conference on Advanced Computer Theory and Engineering (ICACTE): 5 V5484.

Xing W, Wu H, Hao B, Huang W, Liu G. 2013. Bioaccumulation of heavy metals by submerged macrophytes: Looking for hyperaccumulators in eutrophic lakes. Environ Sci Technol 47 (9): 4695-4703.

Yabanli M, Yozukmaz A, Sel F. 2014. Heavy metal accumulation in the leaves, stem and root of the invasive submerged macrophyte Myriophyllum spicatum L. (Haloragaceae): An example of Kadin Creek (Mugla, Turkey). Brazilian Arch Biol Technol 57 (3): 434-440. DOI: $10.1590 /$ S1516-8913201401962 